\title{
Magnesium supplementation of the dairy herd: a case study in Northland and a comparison of two magnesium fertilisers; kieserite and magnesium oxide
}

\author{
M.B.O'CONNOR ${ }^{1}$, M.F.HAWKE ${ }^{2}$, B.J.HUNT ${ }^{3}$, K.ALEXANDER ${ }^{4}$ and A.H.C.ROBERTS ${ }^{5}$ \\ ${ }^{1}$ AgResearch, Ruakura Research Centre, PB 3123, Hamilton \\ ${ }^{2}$ Bay of Plenty Farm and Pastoral Research, PB 3020, Rotorua \\ ${ }^{3}$ Northland Pastoral Research Limited, 4 Barclay Place, Whangarei \\ ${ }^{4}$ Farmer, Northland \\ ${ }^{5}$ Ravensdown Fertiliser, P.O. Box 608, Pukekohe \\ mike.oconnor@agresearch.co.nz
}

\begin{abstract}
Supplementing magnesium $(\mathrm{Mg})$ to dairy cows is widely practised in New Zealand herds. Various methods are used including drenching, pasture dusting, water trough treatment and adding to hay/silage. Following hypomagnesaemia problems on a Northland farm, a capital input of $124 \mathrm{~kg} / \mathrm{ha}$ of magnesium oxide $(\mathrm{MgO})$ was applied in April 2000 followed by annual maintenance rates of $25-30 \mathrm{~kg} \mathrm{Mg} / \mathrm{ha}$ (all as $\mathrm{MgO}$ ). Soil, pasture and animal samples were taken regularly over a 3 year period and in the second year, on-farm management practices were detailed along with climatic conditions. Results indicated a very good lift in soil quick test $\mathrm{Mg}$ (from 16 to 29) with treated pasture averaging 0.21-0.25 $\% \mathrm{Mg}$. In the first year blood serum $\mathrm{Mg}$ levels of the cows (10 sampled on 4 occasions) were all close to optimum at $0.90 \mathrm{mmol} / \mathrm{l}$ but in the second year $(10$ sampled on 6 occasions), there were occasions when levels were lower and in some cases at or below the critical level $(0.62 \mathrm{mmol} / \mathrm{l})$. When farm management practices and climatic conditions were documented in 2001, there were instances when other feedstuffs low in $\mathrm{Mg}$ were fed as a high proportion of the diet leading to less $\mathrm{Mg}$ intake than from treated pasture alone. Also very wet conditions from August through to November led to much pugging damage and presumably poor pasture utilisation and lowered $\mathrm{Mg}$ intake. Although increased soil and herbage $\mathrm{Mg}$ status is useful as a background for maintaining animal performance, there will be times when other Mg supplementation will be necessary. In the Northland case this occurred in the second year after capital $\mathrm{Mg}$ fertiliser had been applied. In separate field trials in Northland and Rotorua, kieserite (magnesium sulphate) was shown to be a quicker acting $\mathrm{Mg}$ fertiliser than Mg. The trials indicated that $25 \mathrm{~kg}$ $\mathrm{Mg} / \mathrm{ha}$ as kieserite generally gave a significant short term lift in pasture $\mathrm{Mg}$ status. If the cost was comparable a "little and often" philosophy of Mg fertiliser application may be a better alternative to a capital plus maintenance approach allowing pasture $\mathrm{Mg}$ to be boosted more quickly at critical periods of the year.
\end{abstract}

Keywords: dairy cows, kieserite, magnesium fertiliser, magnesium oxide, magnesium supplementation

\section{Introduction}

Supplementing magnesium $(\mathrm{Mg})$ as magnesium oxide $(\mathrm{MgO})$ to dairy cows is widely practised in New Zealand dairy herds. Various methods are used including drenching, pasture dusting, water trough treatment and adding $\mathrm{Mg}$ to hay/silage and other feedstuffs (Grace 1996). Fertiliser Mg is also widely used to maintain soil Mg status on farms.

Research has shown that to increase the $\mathrm{Mg}$ status of dairy cows using $\mathrm{Mg}$ fertiliser requires a capital input of $\mathrm{Mg}(120 \mathrm{~kg} / \mathrm{ha})$ followed by annual maintenance $\mathrm{Mg}$ inputs of $25-30 \mathrm{~kg} \mathrm{Mg} / \mathrm{ha}$ (O'Connor et al. 1987).

This paper will present a case study on a Northland dairy farm where following a capital input of $\mathrm{MgO}$, soil, pasture and animal Mg levels were monitored over 3 years. It will show how various on-farm practices interacted with climatic conditions to affect animal Mg status. It will also report field trial results from two sites (Northland and Rotorua) showing Mg uptake by pastures from two $\mathrm{Mg}$ fertilisers, kieserite and $\mathrm{MgO}$.

\section{Methods}

\section{Farm case study}

The Northland farm of Kevin and Michelle Alexander consists of 80 ha of mixed sedimentary (Brown) soils ranging from Wairua clay and Whakapara silt loam on the flats to Marua and Aponga clay on the hills (Alexander $\&$ Mouton 1996). The farm carried 200 Friesian cows ( 2.5 cows $/ \mathrm{ha})$ and produced $900-950 \mathrm{~kg}$ milksolids/ha which is high by Northland standards. Calving starts on 10 July. The farm had a good fertiliser history with soil quick test (QT) levels of $\mathrm{pH}$ 6.0, Olsen phosphorous $34 \mu \mathrm{g} / \mathrm{ml}$, quicktest (QT) Ca 18, QT Mg 16, QT K 6, sulphate-sulphur $14 \mu \mathrm{g} / \mathrm{g}$ and QT Na 6 .

In April 2000, following hypomagnesaemia problems in the herd, a capital dressing of $124 \mathrm{~kg} \mathrm{Mg} /$ ha was applied to the whole farm. Thereafter, annual maintenance dressings of $30 \mathrm{~kg} \mathrm{Mg}$ and $25 \mathrm{~kg} \mathrm{Mg} /$ ha were applied in 
autumn 2001 and 2002 respectively. The opportunity was taken to monitor the benefits of this practice.

In 2001, on-farm management practices along with climate were monitored. Soil, plant and animal Mg measurements were undertaken. Ten cows were selected at random and sampled for blood serum $\mathrm{Mg}$ status on 4 occasions in 2000, 6 in 2001 and 1 in 2002. Two cows were replaced in 2001. Soil and herbage samples were taken from 3 representative paddocks on 1 occasion in 2000 and 6 occasions in 2001 and 2002 and analysed for $\mathrm{Mg}$ and other major elements.

\section{Field trials: magnesium oxide vs kieserite}

Field trials were established in Northland in April 2002 and in Rotorua in June 2003 to compare magnesium oxide $(\mathrm{MgO})$ and kieserite $\left(\mathrm{MgSO}_{4}\right)$ as sources of $\mathrm{Mg}$ for increasing pasture $\mathrm{Mg}$ status. Each trial consisted of 2 products ( $\mathrm{MgO}$ and kieserite), 3 rates (25, 50 and 100 $\mathrm{kg} \mathrm{Mg} / \mathrm{ha}$ ) and 2 times of application (autumn and spring). Each trial had 2 controls and 4 replications. Herbage samples were taken at 3-4 weekly intervals after each application and analysed for $\mathrm{Mg}$ content.

\section{Results}

\section{Blood serum Mg levels in cows}

In 2000 following the capital application of $\mathrm{MgO}$ (April 2000), blood serum Mg levels in the 10 cows sampled were all at or near optimal levels whereas in 2001 levels were lower than optimal (Table 1). This decline between years is illustrated more dramatically when two individual cows are considered rather than the mean (Figure 1). Year 2001 was climatically more difficult than 2000 with higher than normal rainfall from August to December (788 vs $537 \mathrm{~mm}$ ) with wet, waterlogged soils and pugging damage.

Table 1 Blood serum Mg levels in 2000, 2001 and 2002 (mean of 10 cows).

\begin{tabular}{lcl}
\hline & $\begin{array}{c}\text { Blood serum } \\
\text { Mg (mmol/l) }\end{array}$ & \\
\hline 2000 & & \\
May & 0.97 & \\
July & 0.84 & Mean $0.90^{*}$ \\
Sept & 0.87 & \\
Oct & 0.93 & \\
2001 & & \\
March & 1.06 & \\
June & 0.86 & Mean 0.83 \\
July & 0.72 & \\
Sept & 0.88 & \\
Oct & 0.72 & \\
Dec & 0.75 & \\
2002 & 0.96 & \\
Sept & & \\
\hline
\end{tabular}

* optimal level 0.9 - 1.1. mmol//; critical level $0.62 \mathrm{mmol} / \mathrm{l}$.
Figure 1 Blood serum Mg status of two cows (16, 53) on four occasions in 2000 and six occasions in 2001.
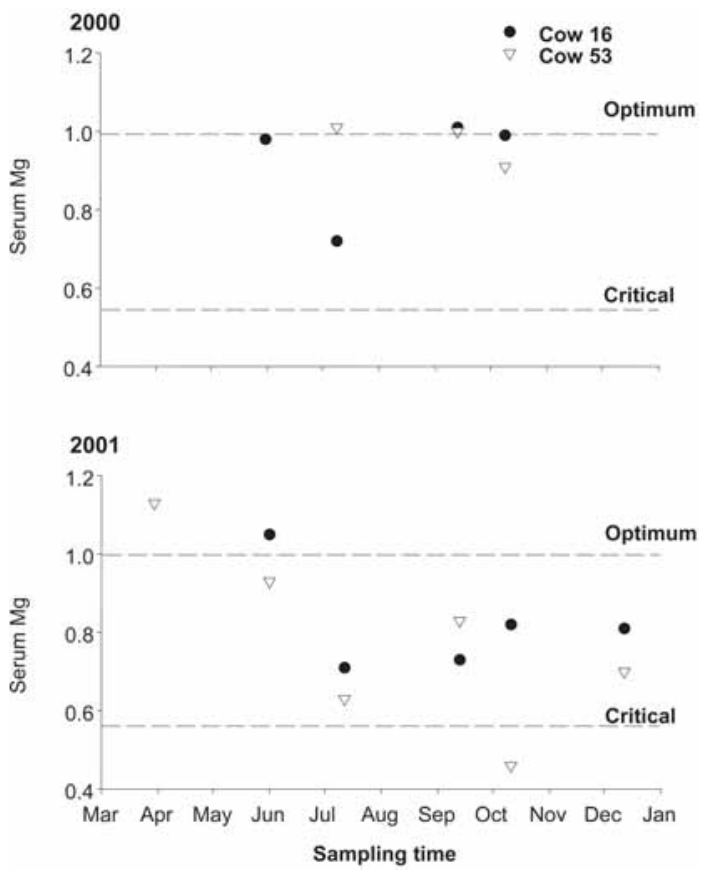

On-farm management

In 2001, various on-farm practices were documented over the period May-December as they impacted on blood serum Mg levels:

a) May to mid-June

Blood Mg levels 30 March 1.06 mmol/1; 1 June 0.86 $\mathrm{mmol} / \mathrm{l}$.

The farmer was offering $16 \mathrm{~kg} \mathrm{DM} /$ cow/day with $6 \mathrm{~kg}$ as pasture, $5 \mathrm{~kg}$ as maize silage and $5 \mathrm{~kg}$ as grass silage. $\mathrm{Mg}$ content of the pasture was $0.24 \%$, the grass silage $0.17 \%$ and the maize silage $0.13 \%$. This means that $\mathrm{Mg}$ intake was some $76 \%$ of what an allgrass diet would be at the same total intake.

b) Mid-June to mid-August

Blood Mg levels 12 July $0.72 \mathrm{mmol} / \mathrm{l}$.

The farmer was feeding all pasture and dusting pastures at $50 \mathrm{~g} \mathrm{MgO} / \mathrm{cow} /$ day. Pasture $\mathrm{Mg}$ content had dropped from 0.24 to $0.21 \%$. Cold wet conditions prevailed.

c) Mid-August to mid-September

Blood Mg levels 13 September $0.88 \mathrm{mmol} / 1$.

The farmer was offering $20 \mathrm{~kg} \mathrm{DM} / \mathrm{cow} /$ day with 16 $\mathrm{kg}$ as pasture, $2 \mathrm{~kg}$ grass silage and $2 \mathrm{~kg}$ meal $/ \mathrm{cow} /$ day. Pasture was being dusted at $100 \mathrm{~g} \mathrm{MgO} / \mathrm{cow} /$ day and cows were being drenched with $30 \mathrm{~g} \mathrm{MgO} / \mathrm{cow} /$ day. Blood serum $\mathrm{Mg}$ levels had lifted slightly.

d) Mid-September to mid-October

Blood Mg level 11 October 0.75 mmol/1. 
Table 2 Pasture Mg content (\%) (2000-2002).

\begin{tabular}{cccc}
\hline Year & No. samples & Mean & Range \\
\hline 2000 & 1 & 0.25 & 0 \\
2001 & 6 & 0.23 & $0.20-0.28$ \\
2002 & 6 & 0.21 & $0.16-0.26$ \\
\hline
\end{tabular}

Figure 2 Pasture $\mathrm{Mg}$ content and blood serum $\mathrm{Mg}$ status $2000-2002$. The optimal blood serum $\mathrm{Mg}$ level is $0.9-1.1 \mathrm{mmol} / \mathrm{l}$; the critical level is $0.62 \mathrm{~m} \mathrm{~mol} / \mathrm{l}$.
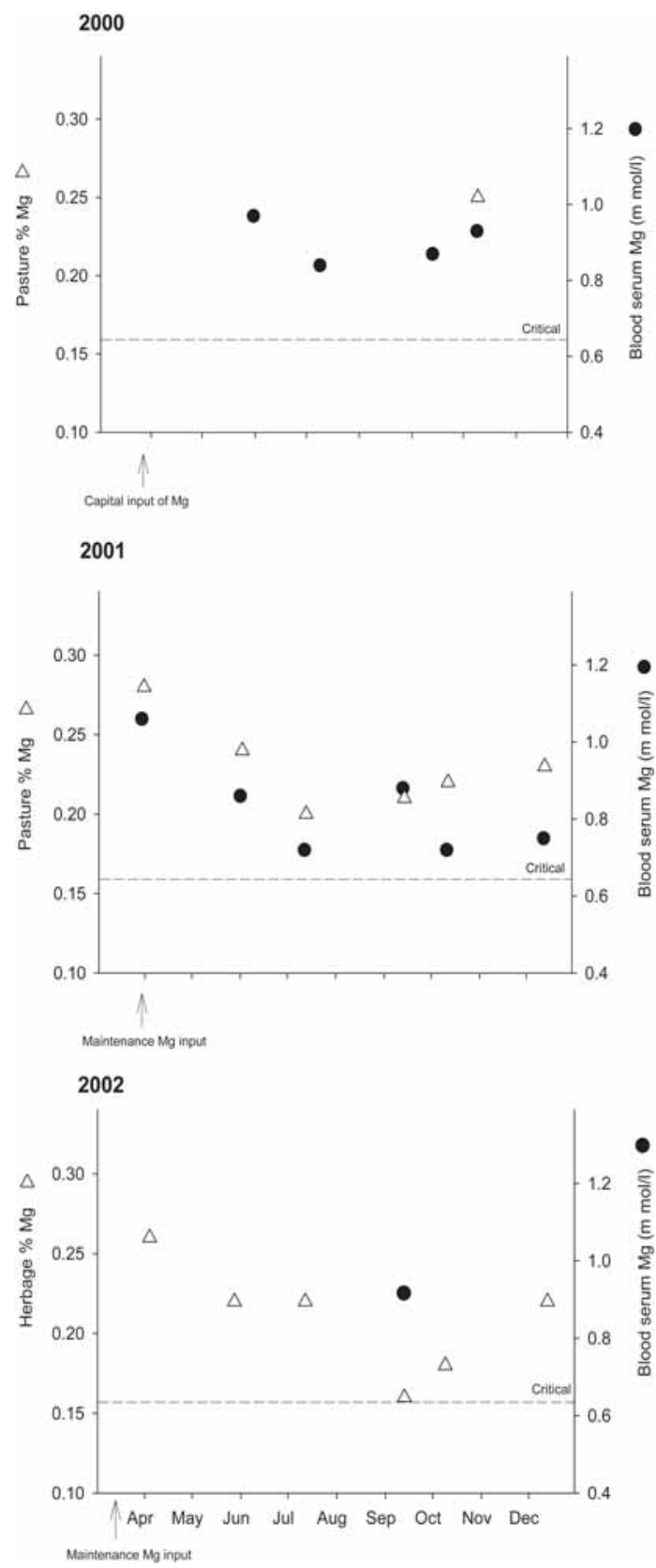

The farmer was offering $20 \mathrm{~kg} \mathrm{DM} / \mathrm{cow} /$ day with 16 $\mathrm{kg}$ as pasture, $2-3 \mathrm{~kg}$ maize silage and $1.5 \mathrm{~kg}$ meal. He drenched with $30 \mathrm{~g} \mathrm{MgO} / \mathrm{cow}$ and applied $30 \mathrm{~g} \mathrm{MgO}$ per cow to the maize silage. Conditions were extremely wet, pastures were pugged and utilisation would have been reduced leading to a fall in $\mathrm{Mg}$ intake. This was in spite of the pasture having $0.22 \%$ Mg. Cow 53 (Figure 1) had a critically low Mg status at this sampling.

e) Mid-October to mid-December

Blood Mg level 12 December $0.75 \mathrm{mmol} / 1$.

The farmer was offering all pasture with $0.23 \% \mathrm{Mg}$. However conditions were still extremely wet with low sunlight, poor pasture utilisation and presumably lowered $\mathrm{Mg}$ intake.

\section{Pasture Mg}

Mg content in pasture for 2000-2002 is shown in Table 2 and as individual cuts related to blood serum $\mathrm{Mg}$ in Figure 2.

$\mathrm{Mg}$ content was generally above $0.20 \%$ for 2000 and 2001 but in 2002 showed values below $0.20 \%$ in September and October. Levels above $0.20 \% \mathrm{Mg}$ are generally considered desirable (Kemp 1960). The low levels are probably a consequence of low temperature and lack of clover growth in those months. In spite of $\mathrm{Mg}$ contents being $0.20 \%$ in 2001, blood serum Mg levels were below optimum on a number of occasions (Figure 2). The reverse was the case in 2002 where in September pasture $\mathrm{Mg}$ was very low $(0.16 \%)$ but blood serum $\mathrm{Mg}$ was near optimum. In this case there was a new herd under different management and unfortunately more animal sampling was not possible through the spring period.

\section{Soil Mg}

Soil quick test Mg levels for 2000-2002 are shown in Table 3. The capital input of $\mathrm{Mg}$ raised soil QT $\mathrm{Mg}$ from 16 to 29 and after two years of maintenance fertiliser $\mathrm{Mg}$ (25-30 kg ha/yr), the QT Mg level was 26. Maintaining soil QT Mg levels at 25-30 should ensure a good background level for animal performance (Roberts \& Morton 1999).

Table 3 QT Mg values (2000-2002). Prior to $\mathrm{Mg} \mathrm{O}$ application, QT Mg was 16.

\begin{tabular}{cccc}
\hline Year & No. samples & Mean & Range \\
\hline 2000 & 1 & 29 & - \\
2001 & 6 & 31 & $26-38$ \\
2002 & 6 & 26 & $20-31$ \\
\hline
\end{tabular}

Field trials

Northland

$\mathrm{Mg}$ content in pasture was significantly higher from 
Figure 3 Northland pasture \% $\mathrm{Mg}$ for control, kieserite and $\mathrm{MgO}$ (autumn and spring applications).
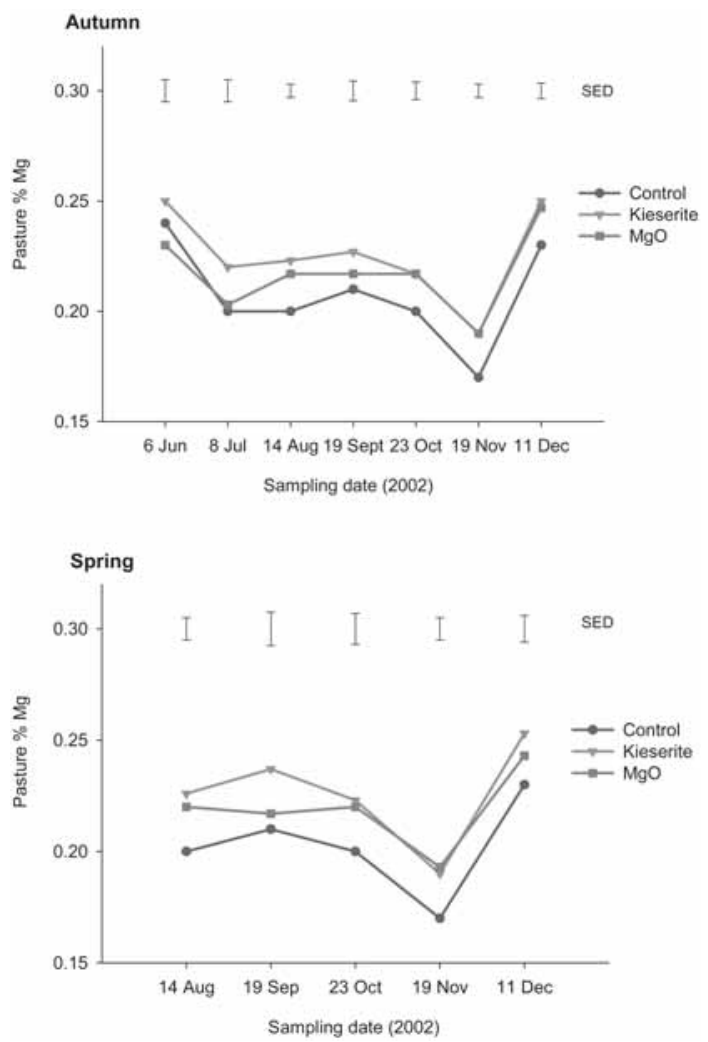

kieserite than $\mathrm{MgO}$ in the first sampling in June after autumn application in April 2002 (Figure 3). Thereafter the difference between products was not statistically different although there was a trend for kieserite to be higher than $\mathrm{MgO}$ through until September. In the spring application both kieserite and $\mathrm{MgO}$ were higher than the control (no Mg) with an initial benefit to kieserite.

In the short term $25 \mathrm{~kg} \mathrm{Mg}$ as kieserite was equivalent to $50-100 \mathrm{~kg} \mathrm{Mg}$ as $\mathrm{MgO}$, showing the quicker acting nature of kieserite.

\section{Rotorua}

$\mathrm{Mg}$ content in pasture was significantly higher from kieserite than $\mathrm{MgO}$ in the first sampling in late-June following an early-June 2003 application (Figure 4). Thereafter there was little difference between products. If the $100 \mathrm{~kg} \mathrm{Mg}$ rate only is considered (data not presented), kieserite was superior to $\mathrm{MgO}$ for the first three samplings (kieserite $0.30 \% \mathrm{Mg}, \mathrm{MgO} 0.26 \%$ $\mathrm{Mg}$ ). In the spring pasture, $\mathrm{Mg}$ content from kieserite was again significantly higher than $\mathrm{MgO}$ at the first sampling with a definite rate effect evident (Table 4). Thereafter there was little difference between products.
Figure 4 Rotorua pasture \% $\mathrm{Mg}$ for control, kieserite and $\mathrm{MgO}$ (autumn and spring applications)
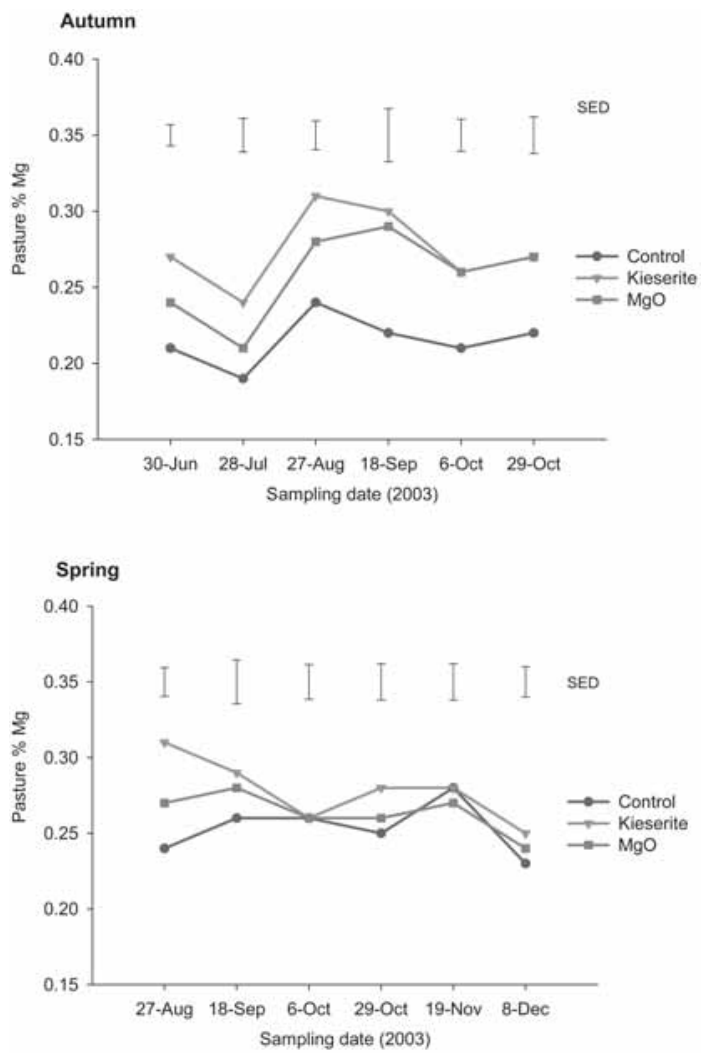

Table 4 Effect of rate of $\mathrm{Mg}$ on pasture $\mathrm{Mg}$ concentration (\%) for spring applied kieserite and $\mathrm{MgO}$, Rotorua. Applied 28 July 2003, harvested 27 August 2003.

\begin{tabular}{lccc}
\hline $\begin{array}{l}\text { Rate }(\mathrm{kg} \\
\mathrm{Mg} / \mathrm{ha})\end{array}$ & \multicolumn{1}{c}{ Kieserite } & $\mathrm{MgO}$ \\
\cline { 2 - 4 } & 0.24 & \\
\hline 25 & 0.28 & 0.24 \\
50 & 0.29 & 0.26 \\
100 & 0.35 & 0.28 \\
SED & & 0.017 & 0.26 \\
\hline
\end{tabular}

\section{Discussion}

The farm case study was useful in highlighting that a capital input of $\mathrm{Mg}$ fertiliser appears to be useful in the first year in lifting soil and plant $\mathrm{Mg}$ status and maintaining blood serum Mg levels in dairy cows. Thereafter, although levels in the soil and pasture were being maintained with maintenance rates of $\mathrm{Mg}$ fertiliser, the ability to maintain blood serum $\mathrm{Mg}$ levels in dairy cows declined. Interactions of climate and type and quantity of supplements fed together with a need for high production all led to problems of maintaining herd blood Mg status. 
This was in spite of additional $\mathrm{Mg}$ supplementation. Certainly a knowledge of the $\mathrm{Mg}$ status of the supplements fed is essential in formulating a $\mathrm{Mg}$ supplementation programme. In spite of problems in maintaining herd Mg status on the study farm in 2001, there is information to suggest that having good background soil $\mathrm{Mg}$ levels does have a benefit on overall herd Mg status (Feyter et al. 1986) and, from farmer experience, cow temperament. Recommended soil QT Mg levels are 25-30 (Roberts \& Morton 1999).

The two field trials have demonstrated that kieserite is quicker acting than $\mathrm{MgO}$. This has been demonstrated elsewhere but long term there has been very little difference shown between Mg products (Hogg \& Karlovsky 1968; Toxopeus \& Gordon 1985).

Because kieserite has generally been more expensive than other $\mathrm{Mg}$ forms it has been ignored in pastoral agriculture but is widely used in horticulture. Currently the cost of kieserite is $\$ 3.10 / \mathrm{kg} \mathrm{Mg}$ versus $0.50 \mathrm{c} / \mathrm{kg} \mathrm{Mg}$ for $\mathrm{MgO}$. However if the cost was to become more comparable to other forms of $\mathrm{Mg}$ it would allow the fertiliser philosophy of capital inputs followed by annual maintenance rates to move to a "little and often" philosophy where a quick acting kieserite could give a short term boost in pasture Mg content. Furthermore these trials have indicated that a low rate of $\mathrm{Mg}$ as kieserite (e.g. $25 \mathrm{~kg} / \mathrm{ha}$ ) could give a significant short term boost in pasture $\mathrm{Mg}$ status.

\section{Conclusions}

Applying capital inputs of $\mathrm{Mg}$ fertiliser followed by annual maintenance rates gives good benefits in the first year but may not completely cover animal needs in subsequent years. This means that other $\mathrm{Mg}$ supplementary measures may be required particularly in adverse climatic conditions when pasture utilisation may be lowered and intake of $\mathrm{Mg}$ curtailed or when supplements of lower Mg content to the treated pasture are fed as a high proportion of the diet. Nevertheless, maintaining soil QT Mg levels at 25-30 should ensure a good background level for animal performance at other than critical periods of the year. Kieserite as a quick acting $\mathrm{Mg}$ fertiliser could have a place in boosting seasonal Mg status and blood serum Mg levels. Cost would be a major determinant of the value of such a policy.

\section{ACKNOWLEDGEMENTS}

Thanks to Ravensdown Fertiliser Co-operative Limited and Kali + Salz, Germany for funding these studies.

\section{REFERENCES}

Alexander, K.; Mouton, N. 1996. Optimising dairy farm returns in summer-dry areas. Proceedings of the New Zealand Grassland Association 57:161-162.

Feyter, C.; Young, P.W.; O’Connor, M.B.; Dyson, C.B. 1986. Magnesium status of dairy herds in Matamata County, New Zealand 1. Associations of serum magnesium and animal management, pasture and soil factors. New Zealand Journal of Experimental Agriculture 14: 183-190.

Grace, N 1996. Managing hypomagnesaemic grass tetany. AgFact 58. AgResearch.

Hogg, D.E.; Karlovsky, J. 1968. The relative effectiveness of various magnesium fertilisers on a magnesium deficient pasture. New Zealand Journal of Agricultural Research 11: 171-183.

Kemp, A. 1960. Hypomagnesaemia in milking cows: the response of serum magnesium to alterations in herbage composition resulting from potash and nitrogen dressing of pasture. Netherlands Journal of Agricultural Science 8: 281-304.

O'Connor, M.B.; Pearce, M.G.; Gravett, I.M.; Towers, N.R. 1987. Fertilising with magnesium to prevent hypomagnesaemia (grass staggers) in dairy cows. Proceedings of the Ruakura Farmers' Conference 39: 47-49.

Roberts, A.H.C.; Morton, J.D. 1999. Fertiliser use on New Zealand dairy farms. DRC/AgResearch/ FertResearch. 36 pp.

Toxopeus, M.R.J.; Gordon, R.B. 1985. Pasture responses to magnesium fertilisers on a yellow-brown pumice soil. New Zealand Journal of Experimental Agriculture 13: 39-45. 
